\title{
Glucose Tolerance and Serum Insulin in Identical Twins of Diabetics
}

\author{
D. A. PYKE, ${ }^{*}$ M.D., F.R.C.P. ; J. CASSAR, † M.D., D.I.C. ; JANET TODD, $\ddagger$ M.D., M.R.C.P. \\ K. W. TAYLOR, $\$ M.B., PH.D.
}

British Medical fournal, 1970, 4, 649-651

\begin{abstract}
Ummary: Glucose tolerance with serum insulin assay $\checkmark$ has been carried out in 24 apparently unaffected identical twins of diabetics. Glucose values were significantly higher and insulin values significantly lower than in control subjects, but there was considerable individual variation and in half the cases glucose tolerance was normal. There was no case of increased insulin response. In these twins glucose tolerance and insulin response were not correlated with weight, family history of diabetes, age at diagnosis of diabetes in the affected twin, time since that diagnosis, nor with age at testing the unaffected twin. On retesting 12 of the twins after two years no significant differences were found from the first testing.

We conclude that not all these twins are likely to develop diabetes, that the assumption that identical twins of diabetics are necessarily "prediabetic" is probably erroneous, and that factors other than genetic ones are important in the aetiology of diabetes.
\end{abstract}

\section{Introduction}

The study of diabetes in twins might be expected to throw light on the inheritance of the condition and possibly on its early development. In this paper we report investigations on 24 pairs of apparently unaffected identical twins of known diabetics. We have already reported our findings in nine of these 24 cases (Pyke and Taylor, 1967).

There have been several case reports of individual pairs of monozygotic twins, one or both of whom have diabetes, but only three large series have been published (Joslin et al., 1959; Harvald and Hauge, 1963; Gottlieb and Root, 1968; Gottlieb et al., 1969). Harvald (1967) found that 58 out of 97 pairs were concordant and predicted that all would eventually become so, but no series has been published in which all pairs were in fact concordant. A study similar to ours is that of Cerasi and Luft (1967), who measured carbohydrate tolerance and insulin response in five unaffected identical twins of diabetics.

\section{Clinical Data}

Some of the twins attended King's College Hospital, but most were referred to us by colleagues in other centres or through the British Diabetic Association. The diagnosis of diabetes in the affected twins was unequivocal, having been made on clinical grounds, usually several years before we tested the unaffected twins. Of the 24, 20 were taking insulin, one was taking a sulphonylurea, and three were on diet alone. That the twins were in fact monozygous was established on clinical grounds and confirmed in 20 pairs by detailed blood grouping (kindly done for us by the Lister Institute Blood Group Reference Laboratory, London) for the following groups: $\mathrm{ABO}, \mathrm{CDE}, \mathrm{MN}, \mathrm{S}, \mathrm{P}, \mathrm{Lu}^{\mathrm{a}}, \mathrm{Le}^{\mathrm{a}}, \mathrm{Le}^{\mathrm{b}}, \mathrm{Fy}^{\mathrm{a}}$. If twins are the same with respect to these blood groups the probability that they are identical is about $98 \%$ (Maynard Smith and Penrose, 1955).

The main clinical features of the 24 pairs of twins are

* Consultant Physician.

† Commonwealth Scholar.

F Formerly Medical Registrar.

Clinical Assistant and Reader in Biochemistry, University of Sussex.

Diabetic Department, King's College Hospital, London, S.E.5 shown in Table I. Of the unaffected twins, four were more than $10 \%$ above expected weight; a family history of diabetes was known in. 15 (first degree relative in four). The time intervals between the diagnosis of diabetes in the affected twin and our testing the apparently unaffected twin was less than 1 year in 4, 1-5 years in 7,6-10 years in 6, 11-15 years in $4,16-20$ years in 0 , and $21-26$ years in 3 . The range was $0-26$ years and the mean interval 7.9 years.

\section{Test Procedure}

The tests on the unaffected twins were done at King's College Hospital or, more often, in the patients' homes. The subjects were taking a free diet; after an overnight fast they had a $50-\mathrm{g}$. oral glucose tolerance test, samples of venous blood being taken before glucose administration and 30,60, and 120 minutes after. Glucose was determined by a glucose oxidase method and serum insulin by a double antibody radioimmunoassay as in our previous paper (Pyke and Taylor, 1967). Results were compared with those obtained from 50 normal controls of similar age and weight studied in our laboratory.

\section{Results}

Blood glucose and serum levels for each of the 24 unaffected twins and mean values are shown in Table II. Mean glucose values were significantly higher in the twins than in the normal controls. Nevertheless, not all the twins had impaired glucose tolerance; in 12 the glucose tolerance tests were normal-that is, all blood glucose values lay within two standard deviations of the mean values for the normal controls. Mean insulin values for the whole group were significantly lower than those of normal controls, but there was considerable individual variation. In no case were serum insulin values, fasting or after glucose, abnormally high.

We have analysed the results according to the age of the twins at the time of testing (Table III). There are no significant differences in glucose or insulin values in 10 twins aged 30 or less and the 14 aged over 30 . The results when the twins are divided by age at diagnosis of diabetes in the affected twin into those aged less than 20 (8) and those aged 20 or more (16) are shown in Table IV. Glucose values at 30 and 60 minutes are slightly higher in the twins of the lateronset diabetics (who were 27 years older at the time of testing), but neither these nor any of the other results are significantly different in the two groups.

Since mean glucose tolerance in these unaffected twins of diabetics was impaired it might be concluded that this was due to a general decline in islet cell function which would culminate in clinical diabetes. To test this hypothesis we have examined our results in relation to the time interval since diabetes was diagnosed in the affected twin. If the apparently unaffected twins were undergoing a progressive deterioration in glucose tolerance then twins of diabetics of long-standing should show a greater impairment of glucose tolerance than twins of more recently diagnosed diabetics. We have therefore divided our results (Table V) into cases where the unaffected twin was tested within 10 years of the diagnosis of diabetes in the affected twin (15) and those in whom the interval was longer (9). The only significant difference 
TABle I.-Twenty-four Pairs of Identical Twins Discordant for Diabetes: Clinical Features

\begin{tabular}{|c|c|c|c|c|c|c|c|c|c|c|c|c|}
\hline \multirow{3}{*}{ Pair } & \multirow{3}{*}{ No. } & & \multirow{3}{*}{ Sex } & \multirow{3}{*}{ Family History of Diabetes } & \multirow{3}{*}{\multicolumn{2}{|c|}{$\frac{\text { Diabetic Twin }}{\text { Treatment }}$}} & \multicolumn{6}{|c|}{ Unaffected Twin } \\
\hline & & & & & & & \multicolumn{2}{|c|}{ Height } & \multicolumn{2}{|c|}{ Weight } & \multirow{2}{*}{$\begin{array}{l}\text { Age } \\
\text { at } \\
\text { lst } \\
\text { Test }\end{array}$} & \multirow{2}{*}{$\begin{array}{l}\text { Age } \\
\text { at } \\
\text { 2nd } \\
\text { Test }\end{array}$} \\
\hline & & & & & & & in. & $\mathrm{cm}$ & lb. & kg. & & \\
\hline $\begin{array}{r}1 \\
2 \\
3 \\
4 \\
5 \\
6 \\
7 \\
8 \\
9 \\
10 \\
11 \\
12 \\
13 \\
14 \\
15 \\
16 \\
17 \\
18 \\
19 \\
20 \\
21 \\
22 \\
23 \\
24\end{array}$ & 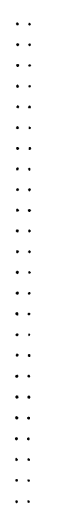 & 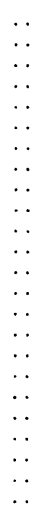 & $\begin{array}{l}\mathbf{F} . \\
\mathbf{M} . \\
\mathbf{M} . \\
\mathbf{F} . \\
\mathbf{M} . \\
\mathbf{F} . \\
\mathbf{F} . \\
\mathbf{F} . \\
\mathbf{F} . \\
\mathbf{F} . \\
\mathbf{F} . \\
\mathbf{F} . \\
\mathbf{M} . \\
\mathbf{M} . \\
\mathbf{M} . \\
\mathbf{F} . \\
\mathbf{F} . \\
\mathbf{F} . \\
\mathbf{M} . \\
\mathbf{M} . \\
\mathbf{F} . \\
\mathbf{F} . \\
\mathbf{F} . \\
\mathbf{F} .\end{array}$ & $\begin{array}{l}\text { Grandfather, } 2 \text { great-aunts, uncle } \\
\text { Maternal aunt, paternal aunt } \\
\text { Father } \\
\text { O } \\
\text { O } \\
\text { Maternal uncle } \\
\text { Mother } \\
\text { Sister } \\
\text { Maternal great-uncle } \\
\text { O } \\
\text { Grandmother, maternal great-aunt } \\
\text { O } \\
\text { First cousin once removed } \\
\text { O } \\
\text { Maternal aunt } \\
\text { O } \\
\text { Paternal great-grandfather } \\
\text { O } \\
\text { First cousin } \\
\text { First cousin } \\
\text { Sister } \\
\text { Great-grandmother, great-great-grandmother }\end{array}$ & $\begin{array}{r}13 \\
52 \\
50 \\
28 \\
28 \\
43 \\
44 \\
44 \\
5 \\
21 \\
29 \\
17 \\
12 \\
26 \\
35 \\
21 \\
15 \\
43 \\
36 \\
5 \\
37 \\
56 \\
4 \\
8\end{array}$ & $\begin{array}{l}\text { Insulin } \\
\text { Diet } \\
\text { Tablets } \\
\text { Insulin, now diet only } \\
\text { Insulin } \\
\text { Insulin } \\
\text { Insulin (has since died) } \\
\text { Insulin } \\
\text { Insulin } \\
\text { Insulin } \\
\text { Insulin } \\
\text { Insulin } \\
\text { Insulin } \\
\text { Insulin } \\
\text { Insulin } \\
\text { Insulin } \\
\text { Insulin } \\
\text { Insulin } \\
\text { Insulin } \\
\text { Insulin } \\
\text { Insulin } \\
\text { Diet } \\
\text { Insulin } \\
\text { Insulin }\end{array}$ & $\begin{array}{l}64 \\
72 \\
63 \\
70 \\
65 \\
63 \\
66 \\
62 \\
61 \\
63 \\
65 \\
51 \\
66 \\
68 \\
63 \\
67 \\
63 \\
68 \\
55 \\
65 \\
64 \\
64 \\
52\end{array}$ & $\begin{array}{l}162.6 \\
182.8 \\
160.0 \\
177.8 \\
165.1 \\
160.0 \\
167.6 \\
157.5 \\
154.9 \\
160.0 \\
165.1 \\
129.5 \\
167.6 \\
172.7 \\
160.0 \\
170.2 \\
160.0 \\
172.7 \\
139.7 \\
165.1 \\
162.6 \\
162.6 \\
132.0\end{array}$ & $\begin{array}{r}99 \\
258 \\
112 \\
151 \\
124 \\
120 \\
140 \\
98 \\
137 \\
147 \\
172 \\
85 \\
133 \\
144 \\
126 \\
126 \\
143 \\
168 \\
79 \\
105 \\
168 \\
126 \\
70\end{array}$ & $\begin{array}{r}44.9 \\
117.0 \\
50 \cdot 8 \\
68 \cdot 5 \\
56 \cdot 2 \\
54 \cdot 4 \\
63 \cdot 5 \\
44 \cdot 5 \\
62 \cdot 1 \\
66 \cdot 7 \\
78 \cdot 0 \\
38 \cdot 6 \\
60 \cdot 3 \\
65 \cdot 3 \\
57 \cdot 2 \\
57 \cdot 2 \\
64 \cdot 9 \\
76 \cdot 2 \\
35.8 \\
47.6 \\
76.2 \\
57.2 \\
31.8\end{array}$ & $\begin{array}{r}23 \\
55 \\
55 \\
31 \\
30 \\
43 \\
44 \\
56 \\
14 \\
45 \\
36 \\
18 \\
13 \\
41 \\
46 \\
28 \\
22 \\
45 \\
48 \\
12 \\
58 \\
56 \\
30 \\
8\end{array}$ & $\begin{array}{l}26 \\
58 \\
34 \\
32 \\
46 \\
47 \\
58 \\
17\end{array}$ \\
\hline
\end{tabular}

TABLE II.-Glucose Tolerance and Serum Insulins in the Apparently Unaffected Identical Twins of Diabetics and in 50 Normal Subjects

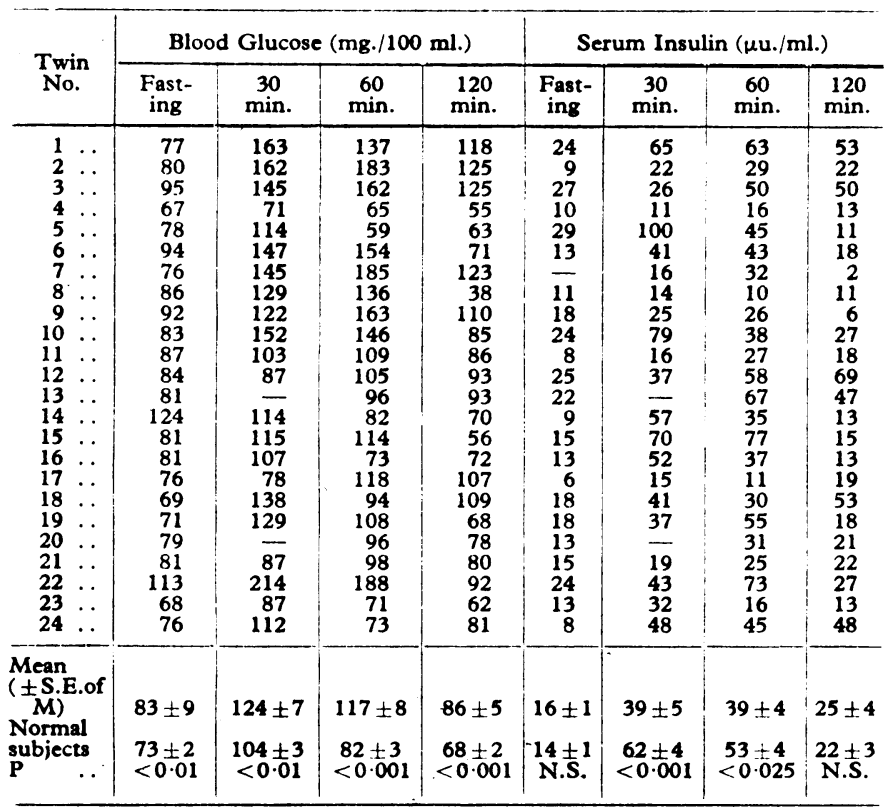

TABLE VI.-Repeat Glucose Tolerance and Serwm Insulins After Two Years in Twelve Identical Twins of Diabetics

\begin{tabular}{|c|c|c|c|c|c|c|c|c|}
\hline & \multicolumn{4}{|c|}{$\begin{array}{c}\text { Blood Glucose } \pm \text { S.E. of Mean } \\
(\mathrm{mg} . / 100 \mathrm{ml} .)\end{array}$} & \multicolumn{4}{|c|}{$\begin{array}{l}\text { Serum Insulin } \pm \text { S.E. of } \\
\text { Mean }(\mu \mathrm{u} . / \mathrm{ml} .)\end{array}$} \\
\hline & 营 & $\begin{array}{l}\text { 家 } \\
\text { 足 }\end{array}$ & $\begin{array}{l}\text { 离 } \\
8 \\
8\end{array}$ & 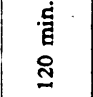 & 总 & $\begin{array}{l}\stackrel{\dot{B}}{E} \\
\text { 品 }\end{array}$ & 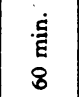 & 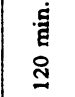 \\
\hline $\begin{array}{l}\text { First test } \\
\text { Second test }\end{array}$ & $\begin{array}{l}86 \pm 4 \\
80 \pm 4\end{array}$ & $\begin{array}{l}120 \pm 9 \\
116 \pm 9\end{array}$ & $\begin{array}{l}120 \pm 12 \\
104 \pm 13\end{array}$ & $\begin{array}{c}87 \pm 8 \\
80 \pm 12\end{array}$ & $\begin{array}{l}19 \pm 1 \\
16 \pm 1\end{array}$ & $\begin{array}{l}37 \pm 8 \\
41 \pm 6\end{array}$ & $\begin{array}{l}39 \pm 5 \\
46 \pm 8\end{array}$ & $\begin{array}{l}26 \pm 6 \\
27 \pm 8\end{array}$ \\
\hline
\end{tabular}

between the two groups is in the glucose values at 120 minutes, when the figure is actually lower in the twins of diabetics diagnosed more than 10 years previously.

Finally, we have retested 12 of the twins after two years, the results being shown in Table VI. There is no significant difference in glucose or insulin values between the first and second tests.

\section{Discussion}

These results show, as do those of Cerasi and Luft (1967), that the mean glucose tolerance of identical twins of diabetics is impaired as compared with control subjects, but, nevertheless, in about half the cases the glucose tolerance test is normal. We cannot relate any clinical features, such as age, weight, or family history, to the moderate impairment of glucose tolerance in some of these twins.

Serum insulin values in the twins show an impaired response despite higher glucose levels, in contrast to the findings of Gottlieb et al. (1969). Thus the suggestion that diabetes may be induced by a resistance to the action of insulin (Vallance-Owen, 1969) is not supported by our results nor by those of Cerasi and Luft (1967). Whatever the significance of the mild impairment of glucose tolerance and insulin release in our twins there is no evidence from this study that it is a progressive process. It might be argued that all or most of these twins were destined to develop diabetes and that, as time passes, glucose tolerance will deteriorate. There is no evidence of this in the 12 cases in which we have repeated glucose tolerance testing after two years; indeed, there is a remarkable similarity in the results in the two tests. Furthermore, if these apparently unaffected twins were destined to develop diabetes one would expect to find that those whose twin had only recently become diabetic would show less impairment of glucose tolerance than those whose twin had been diabetic for a long time; but we do not find this. In nine of the 24 pairs diabetes had been discovered in the

TABLE III.-Glucose Tolerance and Serum Insulins in the Identical Twins of Diabetics in Relation to Age at Time of Testing

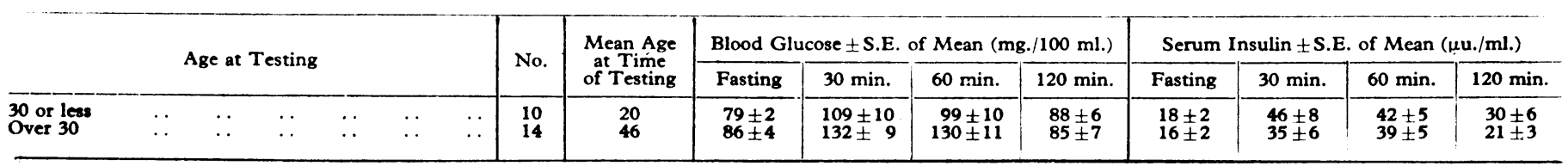


TABLE IV._Glucose Tolerance and Serum Insulins in Identical Twins of Diabetics According to Age at Diagnosis of Affected Twins

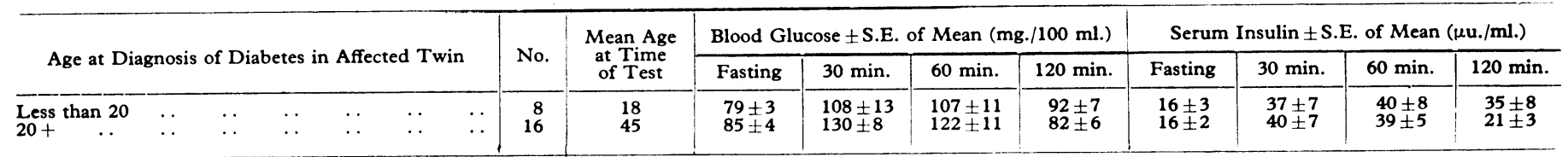

TABLE V.-Glucose Tolerance and Serum Insulins in Identical Twins of Diabetics Tested within 10 Years of, or More than 10 Years after, the Diagnosis of Diabetes in the Affected Twin

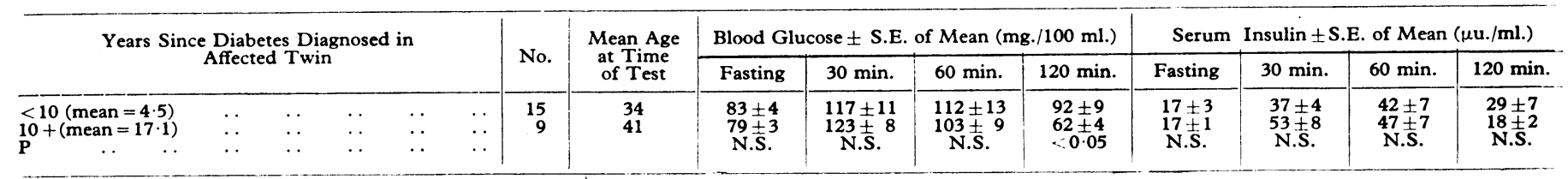

affected twin more than 10 years before we tested the other, yet the glucose and insulin values for these nine show no significant difference from the rest (except at 120 minutes, when it was actually better).

In one pair-No. 23 in Table I, which has been reported separately (Malins et al., 1970)-a twin showed normal glucose tolerance, even in late pregnancy, 26 years after her sister had developed diabetes and 20 years after she herself had shown a highly abnormal glucose tolerance test immediately after an appendicectomy.

All these results cast doubt on the idea of a progressive deterioration of glucose tolerance in identical twins of diabetics leading eventually to $100 \%$ concordance (Harvald, 1967). It is often assumed that all identical twins of diabetics are "prediabetic"-that is, certain to become diabetic. If this were so it would follow that diabetes was exclusively a genetic disease. Our results are consistent with the view that the aetiology of diabetes depends on several factors and that an inherited element is only one of the components in its causation, perhaps not such an important one as is often supposed (Pyke, 1970).

We are grateful to the British Diabetic Association for the support they have given in many ways to this work; also to our colleagues for referring cases and to the twins for their willing co-operation.

\section{REFERENCES}

Cerasi, E., and Luft, R. (1967). Acta Endocrinologica (Kobenhavn), 55, 330. Gottlieb, M. S., and Root, H. F. (1968). Diabetes, 17, 693.

Gottlieb, M. S., Soeldner, J. S., and Gleason, R. E. (1969). Diabetes, 18, Suppl. No. 1, p. 357

Harvald, B. (1967). Acta Medica Scandinavica, Suppl. No. 476, P. 17.

Harvald, B., and Hauge, M. (1963). Acta Medica Scandinavica, 173, 459.

Joslin, E. P., Root, H. F., White, P., and Marble, A. (1959). The Treatment of Diabetes Mellitus, 10th edn. London, Kimpton.

Malins, J., Cassar, J., and Pyke, D. A. (1970). Diabetes. In press.

Pyke, D. A. (1970). Postgraduate Medical fournal, 46, 604.

Pyke, D. A. and Taylor, K. W., (1967). British Medical fournal, 4, 21.

Smith, S. M., and Penrose, L. S. (1955). Annals of Human Genetics, 19, 273

Vallance-Owen, J. (1969). In Diabetes, ed. J. Ostman, p. 243. Amsterdam, Excerpta Medica.

\title{
Single-dose Therapy with Streptomycin and Sulfametopyrazine for Bacteriuria during Pregnancy
}

\author{
J. D. WILLIAMS, ${ }^{*}$ M.D., B.SC., M.R.C.PATH. ; EDNA K. SMITH, † M.B., M.R.C.o.G.
}

British Medical fournal, 1970, 4, 651-653

\begin{abstract}
Cummary: One hundred and sixty-three patients with bacteriuria in pregnancy were treated with a single dose of antibiotic. Four regimens were used: sulfadoxine (sulphormethoxine) 2 g., sulfametopyrazine 2 g., streptomycin $1 \mathrm{~g}$., and a combination of sulfametopyrazine $2 \mathrm{~g}$. and streptomycin $1 \mathrm{~g}$. The highest cure rate of $77 \%$ was achieved with streptomycin and sulfametopyrazine. The long-acting sulphonamides alone gave a cure rate of $55 \%$ while streptomycin alone eradicated $43 \%$ of the infections. Despite the high cure rate with combined therapy bacterial resistance developed in some cases.
\end{abstract}

\section{Introduction}

In selecting chemotherapy for treatment of bacteriuria during pregnancy the clinical and social conditions of the patients must be considered in addition to the infecting organisms. To avoid side effects and toxicity to the fetus the amount of

* Consultant Bacteriologist.

+ Research Registrar.

Dudley Road Hospital, Birmingham 18 chemotherapy should be the smallest necessary to eradicate the infection, and short courses are as effective as is prolonged therapy (Williams et al., 1965, 1968). The reluctance of patients to complete a course of treatment has recently been re-emphasized (Sprunt, 1970), particularly among the poor. Pregnant women of high parity tend not to take their iron tablets.

In our antenatal clinic, where $70 \%$ of patients belong to socioeconomic groups 9,10 , or greater, and $15 \%$ cannot understand English, there has been additional urgency to find an effective form of treatment which can be given in the clinic in one dose. The recent introduction of ultra-longacting sulphonamides which maintain therapeutic levels of sulphonamide in the urine and serum for one week led us to try two of these compounds, sulfadoxine $\ddagger$ and sulfametopyrazine, for this purpose. We have also treated a few patients with streptomycin alone, and finally a group with a combination of sulfametopyrazine and streptomycin. In all cases only one dose of the drug was given.

$\ddagger$ The name sulfadoxine replaced sulphormethoxine as the approved title from January 1969. 